\title{
Universal competence of intercultural interaction in learning a foreign language in professional activities
}

\author{
Maria Sergeevna Zavyalova*, Elina Borisovna Kalinichenko, Lyubov Mikhailovna Ivanova, \\ and Marina Nikolaevna Razdobarova \\ Saratov State Vavilov Agrarian University, Department of Foreign Languages and Speech Culture, \\ Saratov, Russia
}

\begin{abstract}
The article is devoted to the problem of formation of universal competencies. The purpose of the work is to determine the optimal conditions for efficient formation of universal competencies of intercultural interaction. The authors substantiate the idea that, along with professional competencies, the employers increasingly demand a high level of universal competencies in modern graduates of higher educational institutions. The article dwells on the peculiarities of formation of intercultural-interaction universal competence as a complex characteristic of the graduate's aptitude to apply the acquired foreign-language knowledge, skills and abilities in standard and professional situations. The research identified the interconnection between the universal professional and general professional competencies. The article considers the subject-oriented methods of teaching a foreign language, which along with the universal competence, contribute to the formation of students' GPC (general professional competencies) and PC (professional competencies). The basic concepts in respect of the above are presented and analysed; the ratio of maturity of this competence in the process of foreign language teaching is highlighted. A number of methods necessary for the formation of intercultural-interaction universal competence were identified for the development of the educational/methodological complex under the discipline "Foreign language in professional activities" within the system of training for the master degree in the field 38.04.01 "Economics". The considered subject will be interesting for specialists in different spheres of humanitarian knowledge: foreign language teachers of higher educational institutions, representatives of educational and methodical associations, methodologists.
\end{abstract}

Keywords: universal competence, intercultural interaction, ratio

\section{Introduction}

\footnotetext{
*Corresponding author: mariazav@inbox.ru
} 
The modern society brings forward a need for new universal-type specialists possessing more than just professional competencies. Defining competencies as complex characteristics of the graduate's aptitude to apply the acquired knowledge, skills and personal qualities in standard and changing situations of professional activity, certain categories of universal competencies are distinguished by higher education standards: operational mindset and critical reasoning; project development and implementation; teamwork and leadership; communication; intercultural interaction; self-organisation and self-development, including health maintenance [1].

It should be noted that Russian and European employers consider universal competencies to be not less important in a specialist with higher education of any profile than professional competencies [2]. Possession of universal competencies contributes to mobility, reliability and creativity of graduates, their potential for lifelong learning.

Universal competencies translate current demands of the society for general cultural and socio-personal qualities of a graduate who completed a higher education programme of appropriate level [3].

The notion of "universal competencies" reflects the integral result of higher education. At the same time, the continuity and consistency of modern education should be considered in conjunction with the results of secondary general and secondary vocational education. This determines not only the approaches to its formation and development, but also the views concerning the extent of a graduate's preparedness for professional activity [4].

The analysis of scholarly literature and pedagogical experience shows that the problem of forming universal competencies is relevant at the present stage. And, given numerous studies in this area, teachers are faced with the question of how, using which approaches and methods, it is possible to create the conditions for their utmost formation [5].

\section{Methods}

The purpose of the present research is to develop due ways for efficient formation of the intercultural-interaction universal competence for the preparation of the sought educational/methodological complex. According to the Federal State Educational Standard, the wording of the universal competence UC-5 is as follows: "able to analyse and take into account the diversity of cultures in the process of intercultural interaction" [6].

The following objectives were addressed in the research:

- to give a definition of the subject of intercultural interaction and provide its proper consideration;

- to determine the parameters for evaluation of maturity of this universal competence in a learner;

- to develop the educational/methodological complex aimed at formation of the universal competence;

- to undertake due questioning of learners.

The following was used as a theoretical framework of the research: analysis of scientific literature; study of pedagogical experience on the subject of the research. The empirical research involved observation methods, experimenting, questioning.

\section{Results}

To handle the first problem, it was necessary to analyse the existing definitions of intercultural interaction. Intercultural interaction is understood as "the process of mutual 
influence of its actors on the consciousness and behaviour of each other / one another, during which mutual coordination of actions is formed, along with joint activities of individuals or groups representing socio-cultural communities, aimed at meeting educational, creative, recreational and other cultural needs" [7]. "Intercultural interaction is a multitude of forms of relationships, socialisation and activities between/among the individuals belonging to different socio-cultural groups" [8].

According to a number of scholars [8,9-12] and others, the main condition for efficient intercultural interaction is adequate mutual understanding, cultural dialogue, tolerance and respect for the culture of communication partners, pluralism.

Thus, the subject of intercultural interaction may be defined as different-level contacts maintained by representatives of different cultures within the framework of equal treatment of all participants, aimed at joint constructive solution of urgent tasks.

The key milestones in the process of formation of the intercultural-interaction universal competence are as follows: consideration of a particular competence in the context of knowledge of norms, values and achievements of culture; the individual's ability to perceive and recognise intercultural diversity in the process of social contacts; tolerance as a fundamental principle of social existence and of any individual's functioning [13].

In order to handle the second objective, it was necessary to formulate the competence manifestation ratios with regard for the educational outcomes stipulated by the Federal State Educational Standard. The ratios are characterised by the established civic and moral values which include respect for human rights and freedoms, tolerance for other people's views that do not contradict to universal and national values, equality of citizens before the law, etc. [14].

While exploring the specifics of the basic professional educational programme in the discipline "Foreign language in professional activity", the authors identified the following ratio of maturity of the intercultural-interaction universal competence: "able to use the methods and skills of effective intercultural interaction".

Based on the formulated ratio of the given competence, the authors believe that it is necessary to use the subject-oriented methods in teaching a foreign language in the course of formation of this competence [15]. When developing the said educational/methodological complex, the authors resorted to such tools as case problems, role playing, business games and group projects.

The case problems included brief description of a problem to be resolved by a learner in the process of interaction with the representatives of other cultures by means of the studied language. For instance: "Conduct a virtual tour of your university for a group of learners from the target-language country", "You are advertising a new product to the representatives of a company from the target-language country. What features of the product will you highlight in the first place?", "You study in a group with participation of international students. Explain to them why you have chosen this particular specialty", etc. The learners' task is to analyse the actions of each participant of the situation, to identify the regularities and mechanisms of necessary behaviour, to choose the focus of own actions [16].

According to the work programme of the discipline "Foreign language in professional activity", role playing was used in class with the following subject plots: employment; preparation for practical training in the country of the studied language; business trip; organisation of international conference; interview with a prominent figure who made a brilliant career, etc. RPG games implied playing mise-en-scenes prepared by the teacher in the form of a dialogue or polylogue, discussion, dispute, etc. 
The group projects involved setting up a company in the native country and in the country of the target language (which included choice of name, background, selection of personnel, distribution of duties, formation of departments, etc.); creating and publishing a professionally oriented newspaper in the target language, etc. Joint project activities contribute to growing motivation in the process of learning a foreign language, since every learner has an opportunity to set a goal, to plan own research activity, to choose the level of complexity to match his/her ability. The learner, in the process of collaborative work, develops teamwork skills that will be needed in the future professional life [17].

The use of the presented subject-oriented teaching methods contributes, in addition, to the formation of some other competence groups envisaged by the higher education standard (general professional and professional competencies). The interrelation between the intercultural-interaction universal competence and the GPC (general professional competence) / PC (professional competence) is traced in the integrative knowledge, skills and abilities that a master degree graduate should have: familiarity with achievements of different sciences, including profile areas; the ability to apply professional ethics in education and everyday life; understanding of the system of universal human values; social interaction on their basis, etc. [18].

Based on the results of training in the discipline "Foreign language in professional activities", questioning on the issues of intercultural interaction efficiency was carried out. The survey was held in groups of undergraduates in the profile "Economics". The total number of respondents was $32(100 \%)$. Answering the question about being interested in learning the culture of the target-language countries, $26.3(82.2 \%)$ of the respondents gave a positive reply. The dialogue within the contact work in mixed groups (involving foreign students) was evaluated positively by $29(90.6 \%)$ of the respondents. The obtained data make it possible to draw a conclusion on efficiency of the developed educational/methodological complex for the formation of the intercultural-interaction universal competence.

\section{Discussion}

The intercultural-interaction universal competence manifestation ratios, as highlighted by the scientists from various educational organisations, can be split into several groups having common features: specific cultural diversity of the society treated in terms of linguistic, ethnic, religious and social contexts; awareness of the need for constructive intercultural interaction in social, personal and professional sphere; search and use of information on specific features of particular social groups, necessary in terms of intercultural interaction; building an intercultural dialogue with regard for the rules of intercultural interaction in everyday life and in professional activities (respect for an interlocutor, balanced judgement, showing interest in a conversation partner, openness and trust); selection and use of effective and appropriate ways and means of communication in the process of interaction [19].

\section{Conclusion}

Thus, the formation of the intercultural-interaction universal competence should be based on axiological content of all types of educational activities. The practical significance of the research lies in the development of the educational/methodological complex where the authors realised the continuity of levels and stages of education; used the practice-oriented, 
interactive and reflective means of competence formation; highlighted the interrelation between the universal competence and the general professional/ professional competencies provided for by the higher education standard.

In the future, it is planned to undertake a detailed study of the ratio selected by the authors in terms of its descript, since this issue requires additional thorough research.

\section{References}

1. D.S. Rychen, L.H. Salganik, Key Competencies for a Successful Life and a Well-Functioning Society (Hogrefe\&Huber Publishers, Göttingen, 2006)

2. B.H. Spitzberg, G. Changnon, Conceptualizing intercultural competence, in D.K. Deardorff (ed), The SAGE Handbook of Intercultural Competence (Sage, Thousand Oaks, 2009)

3. I. Frumin, M. Dobryakova, K. Barannikov, I. Remorenko, Universalnye kompetentnosti i novaya gramotnost. Chemu uchit segodnya dlya uspekha zavtra [Universal competencies and new literacy. What to teach today for success tomorrow] Teacher's Newspaper, 30 (2018)

4. Izmerenie i otsenka sformirovannosti universalnykh kompetentsii studentov pri osvoenii obrazovatelnykh programm bakalavriata, magistratury, spetsialnosti [Measurement and assessment of the formation of universal competencies of students in the development of educational programs of bachelor's, master's, specialty], I.Yu. Tarkhanova (ed) (RIO YaGPU, Yaroslavl, 2018)

5. L. M. Kalyanova, Revista Inclus, 7, 137-146 (2020)

6. Federalnyi gosudarstvennyi obrazovatelnyi standart vysshego obrazovaniya po napravleniyu podgotovki 38.04.01 Ekonomika (uroven magistratury) [Federal State educational standard of higher education in the field of training 38.04.01 Economics (Master's degree level)]. Accessed on: October 12, 2021. [Online]. Available: http://fgosvo.ru/uploadfiles/FGOS\%20VO\%203++/Mag/380401_M_3_31082020.pdf

7. T.G. Kiseleva, Yu.D. Krasilnikov, Socio-cultural activities (MGUKI, Moscow, 2004)

8. A.P. Sadokhin, Introduction to the theory of intercultural communication (KIORUS, Moscow, 2014)

9. W.B. Gudykunst, Interkultural Communication Theory. Current Perspectives (Newbury Park, 1983)

10. W.B. Gudykunst, Communications with Strangers. An Approach to intercultural communication (New York, 1984)

11. E.M. Vereshchagin, V.G. Kostomarov, Language and culture (Moscow, 1990)

12. S.G. Ter-Minasova, Language and intercultural communication (Moscow University Press, Moscow, 2004)

13. A.A. Pogodina, Podgotovka budushchikh uchitelei k vospitaniyu tolerantnosti u shkolnikov [Preparing future teachers for fostering tolerance in school-children], $\mathrm{PhD}$ thesis in Education (YaGPI, Yaroslavl, 2006)

14. D.M. Bondarenko, et al., Hist Modern, 2, 153-184 (2007)

15. M.N. Razdobarova, et al., Informatsionnye tekhnologii v protsesse formirovaniya mezhkulturnoi kommunikativnoi kompetentsii [Information technologies in the process of formation of intercultural communicative competence], in European Proceedings of 
Social and Behavioural Sciences EpSBS. International Scientific Conference dedicated to the 80th anniversary of Turkayev Hassan Vakhitovich. Kh. I. Ibragimov Complex Research Institute, 2313-232, Grozny, Russia (2020). 10.15405/epsbs.2020.10.05.305

16. S. Asranov, Sh. Abduganieva, Int J Orange Tech, 03, 05 (2021)

17. V. Kalamazh, Probl Psyc 21st Century, 10(1) (2016)

18. A. Dolgorukov, Metod case-study kak sovremennaya tekhnologiya professionalno-orientirovannogo obucheniya [Case-study method as a modern technology of student's professionally-oriented teaching]. Accessed on: October 12, 2021. [Online]. Available: https://studopedia.org/1-82443.html

19. M.S. Zavyalova, Sci Notes Lesgaft Univ, 12(166), 77-82 (2018) 